\title{
Prevalensi Cacing Fasciola Hepatica Pada Sapi Akseptor Program Upsus Siwab Di Kabupaten Muna
}

\section{Prevalence of Fasciola Hepatica Worms in Cattle Upsus Siwab Program Acceptors in Muna Regency}

\author{
Deki Zulkarnain $^{\text {1) }}$, A. Selamet Aku' ${ }^{\text {1) }}$ Rahmatullah ${ }^{\text {1) }}$, dan Laode Muh Munadi ${ }^{1)}$ \\ 1) Jurusan Peternakan, Fakultas Peternakan Universitas Halu Oleo \\ Jl. H.E.A Mokodompit, Kampus Baru, Kota Kendari \\ Immunadi@gmail.com
}

\begin{abstract}
Diterima $\quad: 24$ September 2020
Disetujui : $\quad 20$ Februari 2021

Diterbitkan : 28 Februari 2021
\end{abstract}

\begin{abstract}
Abstrak: UPSUS SIWAB adalah program pemerintah yang bertujuan untuk meningkatkan populasi sapi melalui perbaikan manajemen pemeliharaan dan reproduksi ternak. Salah satu kendala dalam pencapaian program tersebut adalah infeksi penyakit. Infestasi parasit cacing dilaporkan mampu menurunkan produktivitas ternak seperti penurunan bobot badan, daya kerja, kualitas daging, kulit, jeroan, dan terhambatnya pertumbuhan pada sapi muda serta berpotensi sebagai penular penyakit pada manusia (agen zoonosis). Penelitian ini bertujuan untuk mengetahui prevalensi cacing Fasciola hepatica (F. hepatica) pada sapi akseptor program UPSUS SIWAB di Kabupaten Muna. Sebanyak 270 sampel feses sapi dikoleksi dari sembilan kecamatan menggunakan metode random sampling. Variabel yang diamati, yaitu jenis telur cacing yang menginfestasi sapi akseptor menggunakan metode natif dan pembesaran mikroskop $100 x$ (10x10). Selanjutnya, data dianalisis menggunakan persamaan prevalensi. Hasil studi menunjukkan bahwa tingkat prevalensi kejadian F. hepatica di Kabupaten Muna adalah 4,9\%. Berdasarkan lokasinya, infestasi cacing F. hepatica dideteksi pada sapi akseptor yang tersebar di lima kecamatan, yaitu Kecamatan Parigi (o,74\% ; 2/270), Lasapela (o,37\% ; 1/270), Kabawo (2,59\% ; 7/270), Watopute $(0,37 \% ; 1 / 270)$ dan Tangkuno Selatan (o,74\% ; 2/270). Faktor yang diduga berpengaruh terhadap variasi infeksi ini adalah sistem pemeliharaan ternak, keberadaan inang perantara dan tampungan air serta metode diagnose yang digunakan pada studi ini.
\end{abstract}

Kata Kunci: Fasciola Hepatica, UPSUS SIWAB, Kabupaten Muna

Abstract: UPSUS SIWAB is a government program that aims to increase the cattle population through improvement of livestock maintenance and reproduction management. One of the obstacles in achieving the program is the infection of the disease. Worm parasite infestations are reportedly able to reduce livestock productivity such as weight loss, working power, meat quality, skin, offal, and inhibition of growth in heifers as well as potentially contagion of diseases in humans (zoonotic agents). This study aims to determine the prevalence of Fasciola hepatica (F. hepatica) worms in cattle acceptance program UPSUS SIWAB in Muna Regency. A total of 270 samples of cow faeces were collected from nine sub districts using random sampling methods. The observed variable, namely the type of worm egg that infests the acceptor cow using the method of natif and magnification of the microscope 10ox (10x10). Furthermore, the data were analyzed using prevalence equations. The results of the study showed that the prevalence of the incidence of F. hepatica in Muna Regency is $4.9 \%$. Based on its location, the infestation of $F$. hepatica worms was detected in the acceptance cows scattered in five sub districts, Parigi Subdistrict (0.74\% ; 2/270), Lasapela (0.37\% ; 1/270), Kabawo (2.59\%; 7/270), Watopute (0.37\% ; 1/270) and South Tangkuno $(0.74 \% ; 2 / 270)$. Factors suspected to influence the variety of infections are the livestock maintenance system, the presence of intermediate host and water reservoir as well as the diagnosis method used in this study.

Keywords: Fasciola Hepatica, UPSUS SIWAB, Muna Regency

\section{Pendahuluan}

Sektor peternakan merupakan salah satu penyedia pangan hewani terbesar untuk kebutuhan manusia. Kebutuhan pagan hewani merupakan hak bagi seluruh masyarakat karena pada dasarnya kebutuhan akan protein yang bersumber dari ternak sangat dibutuhkan dalam kehidupan baik untuk 
pertumbuhan awal maupun perkembangan serta kelangsungan hidup manusia. Peningkatan populasi manusia harus ditunjang dengan ketersediaan pangan yang cukup, di Indonesia secara khusus pemenuhan akan pangan hewani masih tergolong rendah [1].

Pangan secara umum dibagi menjadi dua sumber yaitu pangan yang bersumber dari tumbuhan (nabati) dan pangan yang bersumber dari hewani. Bahan pangan asal ternak adalah daging, susu dan telur yang berfungsi sebagai sumber gizi utama, yakni protein [2]. Peningkatan produksi ternak sebagai sumber protein hewani adalah suatu strategi nasional dalam rangka peningkatan ketahanan pangan yang sangat diperlukan dalam meningkatkan kualitas sumber daya manusia dan pertumbuhan ekonomi Indonesia [3]. Subsektor peternakan merupakan salah satu komoditi penunjang dalam meningkatkan kecerdasan bangsa [4].

Strategi yang dilakukan pemerintah dalam peningkatan produksi peternakan di Indonesia adalah dengan menyusun program yang menggunakan pendekatan dengan peran aktif masyarakat dan elemen-elemen pendukung lainnya yang bertujuan memaksimalkan dan meningkatkan produksi dengan pengembangan daerah pusat produksi peternakan [5]. Mulai tahun 2017, pemerintah menetapkan program peningkatan produksi khususnya ternak sapi melalui program Wajib Bunting (Upsus Siwab). Program tersebut bertujuan untuk memaksimalkan produksi sapi/kerbau betina produktif milik peternak dengan populasi yang ada dengan perbaikan proses perkawinannya, dan betina produktif ini harus dikawinkan, baik dengan inseminasi buatan maupun kawin alam [6]. Pengembangan ini dilakukan secara menyeluruh di Indonesia sehingga dapat memaksimalkan produksi guna kemajuan peternakan kedepan [7].

Salah satu faktor penentu keberhasilan dalam usaha pengembangan ternak sapi adalah aspek manajemen yakni pada aspek kesehatan [8]. Ganguan penyakit sebagai akibat adanya infestasi penyakit yang dapat menggangu kesehatan. Peningkatan produksi dan reproduksi akan optimal, bila secara simultan disertai penyediaan pakan yang memadai dan pengendalian penyakit yang efektif [9]. Diantara sekian banyak penyakit hewan di Indonesia, penyakit parasit masih kurang mendapat perhatian dari para peternak [10]. Penyakit parasitik biasanya tidak mengakibatkan kematian hewan ternak, namun menyebabkan kerugian berupa penurunan kondisi badan dan daya produktivitas hewan sangat besar [11]. Di antara penyakit parasit yang sangat merugikan adalah penyakit yang disebabkan oleh cacing hati Fasciola sp, yang dikenal dengan nama distomatosis, Fascioliasis atau Fasciolosis [12]. Fasciolosis adalah salah satu jenis penyakit parasit yang disebabkan oleh cacing Trematoda Fasciola hepatica dan Fasciola gigantica [13]. Untuk mengetahui tingkat prevalensi Fasciolosis pada ternak sapi akseptor Upsus Siwab di Kabupaten Muna, dilakukanlah penelitian ini.

\section{Materi dan Metode}

\subsection{Waktu dan tempat penelitian}

Penelitian ini dilaksanakan pada bulan Oktober sampai dengan Desember 2019, bertempat di Kabupaten Muna Sulawesi Tenggara. Evaluasi sampel feses sapi akseptor dilakukan di Laboratorium Unit Fisiologi, Reproduksi dan Kesehatan Ternak Fakultas Peternakan Universitas Halu Oleo Kendari.

\subsection{Materi Penelitian}

Alat yang digunakan untuk pemeriksaan telur cacing pada feses sapi akseptor Upsus Siwab antara lain sendok, kantung plastik, alat tulis, kaca preparat, kaca penutup, mikroskop, kamera, buku petunjuk identifikasi cacing serta gambar acuan.

Bahan yang digunakan dalam penelitian ini yaitu feses sapi akseptor Upsus Siwab di Kabupaten Muna, formalin, aquades, dan air.

\subsection{Populasi dan Sampel Penelitian}

Populasi penelitian ini adalah jumlah populasi sapi akseptor di Kabupaten Muna. Sampel penelitian adalah feses sapi akseptor yang berasal dari 9 kecamatan berdasarkan penentuan lokasi dari program Upsus Siwab, yaitu Kecamatan Tongkuno, Parigi, Kabangka, Napabalano, Lasalepa, Kabawo, Watopute, Tongkuno Selatan dan Bone.

Penentuan lokasi penelitian dilakukan dengan metode porposive sampling, yaitu pengambilan sampel secara sengaja dengan ketentuan syarat-syarat program Upsus Siwab. Adapun penentuan pengambilan sampel dilakukan secara random sampling setiap ternak memiliki peluang yang sama untuk diambil menjadi sampel.

\subsubsection{Koleksi sampel}

Sebanyak 270 sampel feses segar yang dikoleksi dari 9 kecamatan (30 sampel/kecamatan) digunakan pada studi ini. Krtiteria sampel yang dikoleksi adalah feses yang didefekasi selama kurang lebih 30 menit. Feses dimasukan ke dalam wadah kantong plastik bersama dengan kapas yang telah diberi formalin 10\% untuk mencegah menetasnya telur cacing parasit selama pengambilan dan penyimpanan sampel. Setiap sampel diberi label yang memuat keterangan kecamatan, desa, dan tempat pengambilan feses. Seluruh sampel yang telah dikoleksi, dibawa ke laboratorium untuk analisis lebih lanjut.

\subsubsection{Pemeriksaan Sampel}

Pemeriksaan sampel feses menggunakan metode natif. Tujuan pemeriksaan tersebut untuk mendeteksi keberadaan telur cacing $F$. hepatica. Pemeriksaan sampel ini dilakukan di laboratorium Fisiologi 
Reproduksi dan Kesehatan Ternak Fakultas Peternakan Universitas Halu Oleo Kendari. Prosedur pemeriksaan metode natif/sederhana sebagai berikut:

a. Mengambil sejumlah kecil feses menggunakan lidi, meletakkan di atas permukaan kaca objek.

b. Memberikan satu tetes akuades pada feses kemudian mengaduk menggunakan lidi.

c. Menutup dengan kaca penutup.

d. Segera memeriksa sampel menggunakan mikroskop dengan pembesaran 100x (10x10).

\subsection{Variabel Penelitian}

Jumlah sampel feses yang positif mengandung telur cacing $F$. hepatica menjadi variable yang dianalis pada penelitian ini. Data yang di peroleh selanjutnya diamati di laboratorium untuk mengidentifikasi frekuensi kehadiran yang ditentukan dengan persamaan :

Prevalensi $=\frac{F}{N} \times 100 \%$

Keterangan: F : Jumlah sampel positif

$\mathrm{N}$ : Total jumlah sampel yang diperiksa

\subsection{Analisis Data}

Data dikumpul dari jumlah sampel yang diamati, kemudian dianalisis secara deskriptif kualitatif.

\section{Hasil dan Pembahasan}

Secara umum, usaha peternakan yang ada di Kabupaten Muna terdiri dari ternak ruminansia besar seperti sapi, kerbau dan kuda serta ternak ruminansia kecil seperti kambing dan babi serta unggas terdiri dari ayam buras, ayam ras petelur, ayam potong dan itik. Populasi ternak dan unggas tersebut dari tahun ke tahun terus mengalami peningkatan. Jenis ternak yang banyak diusahakan di Kabupaten Muna adalah sapi dan kambing, sedangkan jenis unggas yang banyak dibudidayakan adalah ayam buras.

Tahun 2015 populasi ternak sapi di Kabupaten Muna berjumlah 31.778 ekor meningkat menjadi 38.770 ekor pada tahun 2016, kambing mencapai 12.102 ekor tahun 2014 mengalami penurunan pada tahun 2015 menjadi 10.339 ekor. Populasi ternak ayam buras mengalami peningkatan, pada tahun 2015 mencapai 1.445 .398 ekor mengalami peningkatan pada tahun 2015 menjadi 1.483 .824 ekor. Jumlah ternak sapi yang dipotong di Kabupaten Muna pada tahun 2017 berjumlah 2.758 ekor dengan produksi daging sebanyak $220.640 \mathrm{~kg}$ mengalami penurunan pada tahun 2018 menjadi 1.337 ekor dengan jumlah produksi daging sebesar $108.850 \mathrm{~kg}$. Populasi ternak menurut kecamatan dan jenis ternak di Kabupaten Muna tahun 2018 yaitu dapat dilihat pada tabel 1. sebagai berikut:

Tabel 1. Populasi ternak menurut kecamatan dan jenis ternak di Kabupaten Muna tahun 2018.

\begin{tabular}{|c|c|c|c|c|c|c|}
\hline Kecamatan & Sapi Perah & Sapi Potong & Kerbau & Kuda & Kambing & Babi \\
\hline Tongkuno & - & 6.232 & - & 6 & 597 & - \\
\hline Tongkuno Selatan & - & 2.514 & - & 3 & 498 & 135 \\
\hline Parigi & - & 6.338 & 17 & 22 & 572 & 70 \\
\hline Bone & - & 1.885 & 25 & 17 & 603 & - \\
\hline Marobo & - & 526 & 5 & 2 & 473 & - \\
\hline Kabawo & - & 3.089 & 7 & 7 & 1.436 & - \\
\hline Kabangka & 19 & $4 \cdot 309$ & 4 & 5 & 1.256 & - \\
\hline Kontu Kowuna & - & 1.073 & - & 3 & 709 & - \\
\hline Kontunaga & - & 876 & - & - & 1.215 & - \\
\hline Watopute & - & $3 \cdot 553$ & - & - & 622 & - \\
\hline Katobu & - & 149 & - & - & 369 & - \\
\hline Lohia & - & 1.823 & - & - & 1.013 & - \\
\hline Duruka & - & 274 & - & - & 998 & - \\
\hline Batalaiworu & - & 692 & - & - & 301 & - \\
\hline Napabalano & - & 4.648 & 30 & 8 & 502 & - \\
\hline Lasalepa & - & $4 \cdot 420$ & - & - & 328 & - \\
\hline Towea & - & 347 & - & - & 208 & - \\
\hline Wakorumba Selatan & - & 834 & 4 & 4 & 502 & - \\
\hline Pasir Putih & - & 843 & - & - & 408 & - \\
\hline Pasir Kolaga & - & 1.102 & - & - & 427 & - \\
\hline Maligano & - & 1.902 & 38 & - & 422 & 89 \\
\hline Batukara & - & 272 & 3 & - & 309 & - \\
\hline Kabupaten Muna & 19 & $47 \cdot 701$ & 133 & 77 & 13.768 & 294 \\
\hline
\end{tabular}

Sumber: Dinas peternakan Kabupaten Muna, 2018 [27]

Sistem usaha peternakan di Indonesia ada beberapa macam diantaranya untuk tujuan produksi sapi potong, pembibitan dan sapi perah [14]. Pola pemeliharaan ternak yang diterapkan masih menggunakan pola pemeliharaan induk-anak untuk menghasilkan bakalan/pedet [15]. Konsep semacam 
ini sudah diaplikasikan oleh hampir 90\% peternak tradisional di Indonesia, Upaya khusus percepatan peningkatan populasi sapi dan kerbau Bunting, yang lebih dikenal dengan Upsus Siwab merupakan kegiatan yang terintegrasi, menggunakan pendekatan peran aktif masyarakat dengan mengoptimalkan pemanfaatan sumberdaya peternakan untuk mencapai kebuntingan 3 juta ekor dari 4 juta akseptor Sapi/Kerbau pada tahun 2017 [16]. Hasil pemeriksaan sampel feses dengan menggunakan metode natif menemukan bahwa terdapat telur dari golongan trematoda, khususnya telur Fasciola hepatica dengan pemeriksaan sampel dibawa mikroskop dengan pembesaran objektif 1ox seperti gambar 1 di bawah ini.

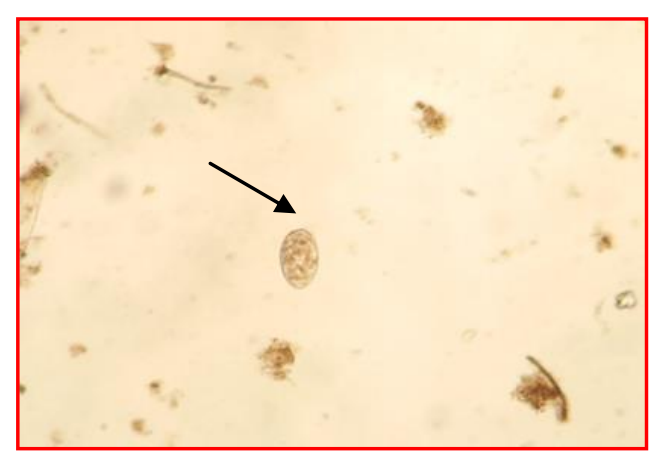

Gambar 1. Panah : telur cacing Fasciola hepatica

Berdasarkan dari hasil pengamatan yang dilakukan di bawah mikroskop terlihat morfologi telur Fasciola hepatica yakni memiliki kerabang telur yang tipis, berbentuk ovoid dengan terdapat operculum di bagian kutubnya. Bagian tubuh terdapat blastomer yang memenuhi rongga telur serta berwarna kekuningan (Gambar 2).

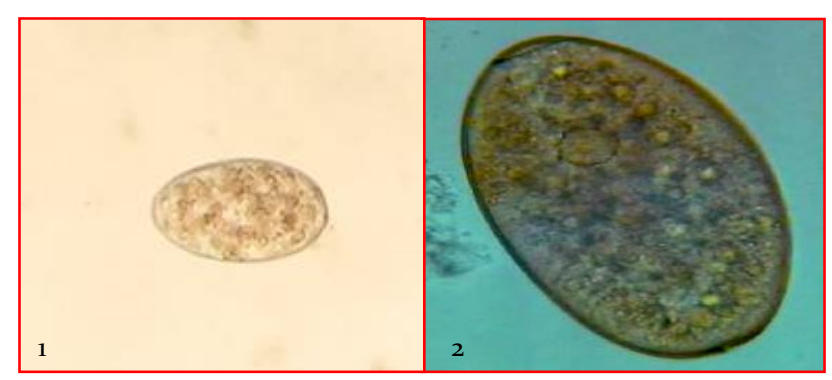

Gambar 2. Hasil pemeriksaan telur Fasciola hepatica

Hasil pemeriksaan telur cacing pada semua sampel feses sapi akseptor menunjukkan 4,81\% terinfeksi $F$. hepatica yang tersebar di Kecamatan Parigi (o,74\% ; 2/270), Lasapela (o,37\% ; 1/270), Kabawo $(2,59 \% ; 7 / 270)$, Watopute $(0,37 \% ; 1 / 270)$ dan Tangkuno Selatan $(0,74 \% ; 2 / 270)$. Sapi-sapi yang dipelihara di Kecamatan Tangkuno, Kabangka, Napabalano dan Bone menunjukkan hasil negatif. Ditinjau dari jumlah sampel per kecamatan, infeksi tertinggi dijumpai pada sapi-sapi yang dipelihara di Kecamatan Kabawo 23,3\% (7/30), diikuti oleh
Kecamatan Parigi dan Tongkuno Selatan 6,6\% (2/30) serta Kecamatan Lasalepa dan Watopute 3,2\% (1/30) (Tabel 2).

Hasil penelitian ini lebih rendah dibandingkan dengan penelitian sebelumnya dengan tingkat infeksi Fasciolosis mencapai 55,48\% di Kabupaten Pesisir (Palembang) dan 18,29\% di Kabupaten Karangasem $[8,16]$. Perbedaan hasil ini dipengaruhi oleh beberapa faktor antara lain kondisi geografis dan keberadaan inang perantara.

Tabel 2. Distribusi Fasciola hepatica pada sapi akseptor di beberapa kecamatan yang tersebar di Kabupaten Muna.

\begin{tabular}{lccc}
\hline \multirow{2}{*}{ Kecamatan } & Jumlah & \multicolumn{2}{c}{ Fasciola hepatica } \\
\cline { 3 - 4 } & Sampel & Positif & Negatif \\
\hline Tongkuno & 30 & 0 & 30 \\
Parigi & 30 & $\mathbf{2}$ & 28 \\
Kabangka & 30 & 0 & 30 \\
Napabalano & 30 & 0 & 30 \\
Lasalepa & 30 & $\mathbf{1}$ & $\mathbf{2 9}$ \\
Kabawo & 30 & 7 & $\mathbf{2 3}$ \\
Watopute & 30 & $\mathbf{1}$ & $\mathbf{2 9}$ \\
Tongkuno Selatan & 30 & $\mathbf{2}$ & $\mathbf{2 8}$ \\
Bone & 30 & $\mathbf{0}$ & 30 \\
\hline Total & $\mathbf{2 7 0}$ & $\mathbf{1 3}$ & $\mathbf{2 5 7}$ \\
\hline
\end{tabular}

Perbedaan tingkat prevalensi di setiap daerah juga dipengaruhi oleh daya tahan metaserkaria di lingkungan serta teknik. Pemilihan teknik diagnose dengan sensitifitas dan spesifisitas yang tinggi akan memberikan hasil yang lebih akurat [12].

Pemeriksaan feses dapat dilakukan dengan metode kualitatif dan kuantitatif [18]. Secara kualitatif dilakukan dengan metode natif, metode apung, metode harada mori, dan metode kato. Metode natif ditujukan untuk pemeriksaan secara cepat (rapid test). Namun demikian, pemeriksaan dengan natif hanya efektif pada kasus infeksi berat dan kurang sensitive untuk kasus infeksi ringan. Konsentrasi telur di dalam feses juga dipengaruhi oleh proses pengeluaran telur yang tidak beraturan dan jumlah telur yang terlalu sedikit dalam feses [19]. Telur cacing yang berada dalam buluh empedu keluar menuju duodenum melalui duktus bilirubin dan akhirnya dikeluarkan bersama feses [20]. Beberapa kasus Fasciolosis ditemukan kejadian obstruksi pada duktus bilirubin akibat migrasi cacing di dalam hati sehingga telur tidak dapat keluar [21].

Faktor terjadinya infeksi Fasciola hepatica diduga berhubungan dengan pola pemeliharaan peternak di Kabupaten Muna. Umumnya ternak dipelihara secara semi intensif dan sebagian daerah pengembalaan memiliki genangan air yang sesuai dengan ekosistem dari $F$. hepatica. serta Manajemen 
Kesehatan ternak di Kabupaten Muna juga terbilang rendah. Terjadinya infeksi helminthiasis Fasciolosis juga dikarenakan pakan yang diberikan pada ternak diperoleh dari daerah yang memiliki genangan air [22]. Cacing fasciolosis berkembang karena adanya genangan air di kisaran tempat pengembalaan ternak [23].

Keparahan infeksi Fasciolosis pada sapi dipengaruhi oleh faktor umur, sistem pemeliharaan dan musim. Sapi yang berumur tua memiliki resiko infeksi terhadap Fasciola sp. lebih tinggi dibandingkan sapi yang berumur muda [24]. Pengaruh umur erat kaitannya dengan kurun waktu infestasi terutama di lapang. Semakin tua umur sapi semakin tinggi frekuensi infeksinya. Kejadian fascioliasis pada sapi muda relatif lebih rendah frekuensinya karena lebih sering dikandangkan dalam rangka penggemukan [25]. Selain itu juga, frekuensi makan rumput sapi muda masih rendah dibandingkan sapi dewasa. Hal ini diduga karena sapi muda masih mengkonsumsi air susu induknya, sehingga kemungkinan untuk terinfekasi larva metacercaria rendah [26].

Sapi yang dipelihara secara ekstensif dilaporkan lebih beresiko terhadap infeksi Fasciola sp., dibandingkan sapi yang dipelihara secara intensif. Sapi yang dipelihara secara ekstensif dilepas di padang pengembalaan dan mencari pakannya sendiri sehingga pakan yang diperoleh tidak terjamin bebas dari larva Fasciola sp. selain itu, sapi yang dipelihara secara ekstensif memiliki peluang lebih tinggi terpapar metaserkaria. Sebagian besar peternak di kecamatan Mallusetasi memelihara sapi secara ekstensif sehingga sapi yang digembalakan memiliki peluang terinfeksi Fasciola sp. relatif tinggi.

Musim juga berpengaruh terhadap derajat prevalensi fasciolosis. Kejadian Fasciolosis banyak terjadi pada awal musim hujan karena pertumbuhan telur menjadi mirasidium cukup tinggi dan perkembangan di dalam tubuh siput mencapai tahap yang lengkap pada akhir musim hujan.

\section{Kesimpulan}

Prevalensi fascioliasis yang disebabkan oleh infeksi $F$. hepatica pada sapi akseptor program UPSUS SIWAB di Kabupaten Muna sebesar 4,9\% berdasarkan pemeriksaan secara natif. Infeksi fascioliasis tertinggi dideteksi pada sapi-sapi yang dipelihara di Kecamatan Kabawo.

\section{Referensi}

[1] Firmansyah, Afzalani, and M. Farhan, "Keanekaragaman Dan Kecukupan Konsumsi Pangan Hewani Dalam Hubungannya Dengan Kualitas Sumberdaya Manusia Keluarga Di Provinsi Jambi," ISSN o852-8349, 2010.
[2] N. S. Wisnujati, "Rencana Aksi Daerah Pangan dan Gizi (RAD-PG) Kabupaten Sampang,” J. Ilm. Sosio Agribis, 16(1): 40-49. 2016

[3] M. Ariani, A. Suryana, S. H. Suhartini, and H. P. Saliem, "Keragaan Konsumsi Pangan Hewani Berdasarkan Wilayah dan Pendapatan di Tingkat Rumah Tangga," Anal. Kebijak. Pertan., 16 (2): 147-163. 2018.

[4] B. Winarso and E. Basuno, "Pengembangan Pola Integrasi Tanaman-Ternak Merupakan Bagian Upaya Mendukung Usaha Pembibitan Sapi Potong Dalam Negeri," Forum Penelit. Agro Ekon., 31 (2): 151-169. 2013.

[5] R. H. Matondang, D. S. Rusdiana, P. Penelitian, D. P. Peternakan, and J. Raya, "Langkah-langkah strategis dalam mencapai swasembada LangkahLangkah Strategis Dalam Mencapai Swasembada Daging Sapi/Kerbau, 32 (3): 131-139. 2014.

[6] I. Inounu, "Supported Science and Reproductive Technology to Achieve Cows Pregnancy Program Succesfully,"Indones. Bull. Anim. Vet. Sci., Wartazoa, 27 (1): 23-34. 2013.

[7] D. Setiawan, "Artificial Insemination of Beef Cattle UPSUS SIWAB Program Based on the Calculation of Non-Return Rate, Service Per Conception and Calving Rate In The North Kayong Regency," Int. J. Trop. Vet. Biomed. Res., 3 (1): 7-11. 2018.

[8] T. Afriani, Y. Yurnalis, F. Arlina, and D. E. Putra, "Analisis Pengetahuan Peternak dan Evaluasi Keberhasilan Program UPSUS SIWAB di Kecamatan Bayang, Kabupaten Pesisir Selatan," J. War. Pengabdi. Andalas, 26 (1): 16-22. 2019.

[9] S. P. Aminuddi, S. B. Alpian, P. Dita, and Kholik, "Identification of gram-negative bacteria of Bali cattle with repeat breeding cases on East Lombok, West Nusa Tenggara Province," in Journal of Physics: Conference Series, 2020. Hal. 1-3. doi: 10.1088/1742-6596/1430/1/012013

[10] Andi Syastiawan, Ahmad Ramdhan, Sitti Nurani "Level of Adoption of Cow Cut Insemination Implementation UPSUS SIWAB In Soppeng District," Am. J. Sustain. Agric., 13 (2): 85-91. 2019.

[11] N. Nursida and I. Sanusi, "Persepsi Peternak dan Penyuluh LapanganTentang Faktor-Faktor Yang Berpengaruh Terhadap Keberhasilan Upsus Siwab di Kabupaten Kutai Timur," J. Pertan. Terpadu, 8 (1): 52-61. 2020.

[12] J. Charlier, J. Vercruysse, E. Morgan, J. Van Dijk, and D. J. L. Williams, "Recent advances in the diagnosis, impact on production and prediction of Fasciola hepatica in cattle," Parasitology, 141 (3): 326-335. 2014.

[13] D. P. Recalde-Reyes, L. Padilla Sanabria, M. I. Giraldo Giraldo, L. J. Toro Segovia, M. M. Gonzalez, and J. C. Castaño Osorio, "Prevalence of Fasciola hepatica in humans and cattle in the 
department of Quindio-Colombia 2012-2013," Infectio, 18 (4): 153-157. 2014.

[14] K. Kusriatmi, R. Oktaviani, Y. Syaukat, and A. Said, "Peranan Teknologi Inseminasi Buatan (IB) pada Produksi Sapi Potong di Indonesia," J. Agro Ekon., 32 (1): 57-74. 2016.

[15] D. Suherman, "Evaluasi Penerapan Aspek Teknis Peternakan pada Usaha Peternakan Sapi Perah Sistem Individu dan Kelompok di Rejang Lebong," J. Sain Peternak. Indones., 3 (1): 35-42. 2015.

[16] S. I G., N. P. Sarini, A. Anton, and A. Wiyana, "Identification Of Reproductive Performance Of Bali Cows (Bos Sondaicus) Artificial Insemination Acceptors In Order To Support The Upsus Siwab Program In Badung And Tabanan Regencies," Maj. Ilm. Peternak., 22 (2): 74-79. 2019.

[17] J. Kardin, D. Dasrul, S. Sugito, N. Nurliana, and T. Z. Helmi, "The Relationship between Farmer Characteristic and Knowledge towards the Successfulness of Cattle Artificial Insemination (AI) in Aceh Besar District," Int. J. Trop. Vet. Biomed. Res., 3 (1): 35-40. 2018.

[18] C. A. Alvarez Rojas, A. R. Jex, R. B. Gasser, and J. P. Y. Scheerlinck, "Techniques for the Diagnosis of Fasciola Infections in Animals. Room for Improvement.," in Advances in Parasitology, 85: Hal 65-107. 2014.

[19] C. Machicado, J. D. Machicado, V. Maco, A. Terashima, and L. A. Marcos, "Association of Fasciola hepatica Infection with Liver Fibrosis, Cirrhosis, and Cancer: A Systematic Review," PLoS Negl. Trop. Dis., 10 (9): 1-11. 2016

[20] J. Pleasance, H. W. Raadsma, S. E. Estuningsih, S. Widjajanti, E. Meeusen, and D. Piedrafita, "Innate and adaptive resistance of Indonesian Thin Tail sheep to liver fluke: A comparative analysis of Fasciola gigantica and Fasciola hepatica infection," Vet. Parasitol., 174 (3-4): 264-272. 2011.

[21] A. K. Howell et al., "Fasciola hepatica in UK horses," Equine Vet. J., 52 (2): 194-199. 2020.

[22] T. H. Le et al., "Development and evaluation of a single-step duplex PCR for simultaneous detection of Fasciola hepatica and Fasciola gigantica (family Fasciolidae, class Trematoda, phylum Platyhelminthes)," J. Clin. Microbiol., 50 (8): 2720-2726. 2012.

[23] W. Saijuntha et al., "Revealing genetic hybridization and DNA recombination of Fasciola hepatica and Fasciola gigantica in nuclear introns of the hybrid Fasciola flukes," Mol. Biochem. Parasitol., 223 (7): 31-36. 2018.

[24] N. Tantri, T. R. Setyawati, and S. Khotimah, "Prevalensi dan Intensitas Telur Cacing Parasit pada Feses Sapi (Bos Sp.) Rumah Potong Hewan (RPH) Kota Pontianak Kalimantan Barat," J. Protobiont, 2 (1): 7-11. 2013.
[25] I. D. Rahayu, "Identifikasi Penyakit pada Pedet Perah Pra-Sapih di Peternakan Rakyat dan Perusahaan Peternakan," J. Gamma, 9 (2): 40-49. 2014.

[26] P. Purwatihningsing, E. Susanto, and M. Qomaruddin, "Perbandingan Prevalensi dan Infeksi Parasit Nematoda pada Sapi Potong Antara Model Kandang Berlantai Beton dengan Berlantai Tanah Di Kecamatan Palang Kabupaten Tuban Tahun 2016," J. Ternak, 7 (2): 1-9. 2016.

[27] Dinas Peternakan Kabupaten Muna"Populasi Ternak Sapi Potong Kabupaten Muna" 2018. 